\title{
AKTIVITAS ANTIBAKTERI FRAKSI ALGA Turbinaria ornata (Turner) J. Agardh YANG DIPEROLEH DARI PERAIRAN TELUK MANADO
}

\author{
Nadia Adam ${ }^{1)}$, Widya Astuty Lolo ${ }^{1)}$, Sri Sudewi ${ }^{1)}$ \\ ${ }^{1)}$ Program Studi Farmasi FMIPA UNSRAT Manado, 95115
}

\begin{abstract}
Marine biota such as algae has been developed to be used as a source of medicinal raw materials in the pharmaceutical industry. Extracs from Turbinaria ornata algae J. Agardh showed antibacterial activity. This study aims to determine the antibacterial activity of the Turbinaria ornata (Turner) J. Agardh fraction obtained from the waters of the Manado Bay against the growth of Staphylococcus aureus and Escherichia coli bacteria. The method used in this study is an experimental laboratory. Turbinaria ornata (Turner) J. Agardh was extracted by maceration method with ethanol $96 \%$ solvent followed by fractionation and antibacterial activity testing with diffusion method. Antibacterial activity was determined based on the results of the clear zone measurements formed around the disc paper. The results showed that the methanol at a concentration of $10 \%, 20 \%, 30 \%$, fractions of $30 \%$ ethyl acetate, and fractions of $20 \%$ and $30 \% n$ hexane, have antibacterial activity which is categorized strongly in both bacteria of S. aureus and E. coli, while ethyl acetate fractions with a concentration of $10 \%$ and $20 \%$ againts S.aureus is in the moderate category. Likewise the antibacterial activity of n-hexane fraction with a concentration of $10 \%$ againts E. coli was included in the medium category.
\end{abstract}

Keywords: Turbinaria ornata (Turner) J. Agardh, antibacterial, Staphylococcus aureus, Escherichia coli

\begin{abstract}
ABSTRAK
Biota laut seperti alga telah banyak dikembangkan untuk digunakan sebagai sumber bahan baku obat dalam industri farmasi. Ekstrak dari alga Turbinaria ornata (Turner) J. Agardh menunjukan adanya aktivitas antibakteri. Penelitian ini bertujuan untuk mengetahui aktivitas antibakteri fraksi Turbinaria ornata (Turner) J. Agardh yang diperoleh dari perairan Teluk Manado terhadap pertumbuhan bakteri Staphylococus aureus dan Escherichia coli. Metode yang digunakan dalam penelitian ini adalah eksperimental laboratorium. Turbinaria ornata (Turner) J. Agardh diekstraksi dengan metode maserasi dengan pelarut etanol $96 \%$ dilanjutkan dengan tahap fraksinasi dan pengujian aktivitas antibakteri dengan metode difusi. Aktivitas antibakteri ditentukan berdasarkan hasil pengukuran zona bening yang terbentuk disekitar kertas cakram. Hasil penelitian menunjukkan bahwa fraksi metanol pada konsentrasi 10\%. 20\% ,30\%, fraksi etil asetat konsentrasi $30 \%$, dan fraksi n-heksana pada konsentrasi 20\%, 30\% memiliki aktivitas antibakteri yang dikategorikan kuat pada kedua bakteri yaitu $S$. aureus dan E. coli, sedangkan fraksi etil asetat dengan konsentrasi $10 \%$ dan $20 \%$ pada bakteri S. aureus termasuk dalam kategori sedang. Begitu pula aktivitas antibakteri fraksi n-heksan dengan konsentrasi $10 \%$ terhadap E. coli termasuk dalam kategori sedang.
\end{abstract}

Kata kunci : Turbinaria ornata (Turner) J. Agardh, antibakteri, Staphylococus aureus, Escherichia coli. 


\section{PENDAHULUAN}

Indonesia mempunyai potensi yang baik untuk mengembangkan dan memanfaatkan kekayaan lautnya termasuk alga. Berbagai penelitian menunjukkan bahwa biota laut memiliki potensi yang sangat besar dalam menghasilkan senyawa-senyawa aktif yang dapat digunakan sebagai bahan baku obat. Biota laut seperti alga telah banyak diteliti dan dikembangkan untuk digunakan sebagai sumber bahan baku obat dalam industri farmasi (Dali et al., 2011).

Alga merupakan hasil perairan laut yang memiliki keanekaragaman hayati serta potensi yang tinggi, diantaranya menghasilkan metabolit sekunder berupa senyawa bioaktif yang beragam dengan aktivitas yang sangat luas sebagai antibakteri, antivirus, anticendawan dan sitotoksik Potensi yang dimiliki oleh alga memungkinkan untuk dimanfaatkan dalam berbagai bidang, terutama bidang nutrasetika dan pengembangan senyawa obat. Sebagian besar senyawa aktif yang terkandung dalam alga menunjukkan aktivitas antibakteri (Rahaweman, 2016).

Pemanfaatan alga dalam bidang farmasi selama ini masih terbatas, sedangkan potensi alga laut Indonesia sangat besar untuk dikembangkan sebagai bahan baku obat yaitu mengandung senyawa bioaktif yang memiliki banyak manfaat dibidang farmasi contohnya senyawa obat sebagai antibakteri. Turbinaria merupakan rumput laut coklat (Phaeophyta). Warna cokelat pada thallus di pengaruhi oleh komposisi pigmen yang terkandung didalamnya, yaitu berasal dari golongan klorofil dan turunannya, golongan karotenoid polar (xantofil), serta golongan karotenoid nonpolar (karoten) (Islami et al., 2014).

Penelitian yang dilakukan Paul (2014) terkait identifikasi senyawa dari turbinaria ornata (Turner) J. Agardh menunjukan adanya senyawa fenolik, polifenol dan tanin yang berkhasiat sebagai antibakteri. Penelitian yang dilakukan Vijayabaskar dan Shiyamala (2011) menunjukan bahwa ekstrak dari Turbinaria ornata (Turner) J. Agardh terdapat senyawa fenolik yang memiliki aktivitas antibakteri terhadap bakteri Staphylococcus aureus dan Escherichia coli.

Bakteri patogen merupakan salah satu penyebab penyakit pada manusia dan makhluk hidup lainnya. Banyak usaha yang telah dilakukan untuk mengantisipasi pengaruh bakteri patogen tersebut yaitu dengan menemukan senyawa kimia yang dapat menghambat pertumbuhan dan membunuh bakteri (Juariah, 2014). Antibakteri diperlukan untuk mengobati infeksi yang disebabkan oleh bakteri.

Penelitian ini dilakukan penentuan aktivitas antibakteri fraksi alga Turbinaria ornata (Turner) J. Agardh yang diperoleh dari perairan Teluk Manado. Uji aktivitas dilakukan terhadap dua jenis mikroba yaitu Staphylococus aureus dan Escherichia coli.

\section{METODOLOGI PENELITIAN}

\section{Waktu dan Tempat Penelitian}

Penelitian ini dilaksanakan pada bulan November 2018 - April 2019 di Laboratorium Taksonomi Jurusan Biologi, Laboratorium Farmakognosi Fitokimia dan Laboratorium Mikrobiologi Farmasi Program Studi Farmasi Universitas Sam Ratulangi.

\section{Bentuk Penelitian}

Penelitian ini menggunakan metode eksperimental laboratorium .

\section{Alat dan Bahan}

a. Alat

Alat yang digunakan dalam penelitian ini yaitu, jas lab, gunting, alat Diving, kantong plastik, kamera bawah laut (Xiomi), zipper bag, ice packs, pisau, blender (Philips), Erlenmeyer (Pyrex), 
rotary evaporator (Steroglass), timbangan analitik (Kern), gelas ukur (Pyrex), gelas kimia (Pyrex), cawan petri (Normax), corong pisah, autoklaf $(A L P)$, pinset, spatula, pembakar spritus, magnetic strirrer, pipet tetes, jarum ose, L glass, batang pengaduk, Laminar air flow ( $N$ Biotek), rak tabung reksi, tabung reaksi (Pyrex), lemari pendingin (Samsung), inkubator (Ecocell), cakram (paper disc), mikropipet (Ecopipette), vial, pot salep, jangka sorong.

\section{b. Bahan}

Bahan-bahan yang digunakan yaitu alga Turbinaria ornata (Turner) J. Agardh, bakteri uji Staphylococcus aureus ATCC 25923, Escherichia coli ATCC 25922 , etanol, metanol, etil asetat, n-heksan, Larutan $\mathrm{H}_{2} \mathrm{SO}_{4} 1 \%$, Larutan $\mathrm{BaCl}_{2} \cdot 2 \mathrm{H}_{2} \mathrm{O}$ 1,75\%, $\mathrm{NaCl} 0,9 \%$, Nutrien Agar, kertas cakram Kloramfenikol, label, alkohol, aquades, spidol permanen, tissue, aluminium foil, kertas saring, kapas, wadah maserasi, plastik wrap, masker, sarung tangan.

\section{Prosedur Penelitian}

\section{Ekstraksi}

Sampel Turbinaria ornata (Turner) J. Agardh sebanyak $1 \quad \mathrm{~kg}$ diekstraksi menggunakan metode maserasi dengan pelarut etanol $96 \%$ sebanyak 3 L sampai sampel terendam secara keseluruhan selanjutnya direndaman selama 3 hari dan sesekali diaduk. Sampel yang telah direndam disaring dengan menggunakan kertas saring menghasilkan filtrat 1 dan debris 1 .

Selanjutnya proses remaserasi selama 2 hari dengan merendam debris 1 dengan pelarut etanol $96 \%$ sebanyak 3 L. Setelah 2 hari sampel tersebut disaring menggunakan kertas saring menghasilkan filtrat 2 dan debris 2. Filtrat 1 dan 2 dicampurkan menjadi satu kemudian disaring, lalu hasil penyaringan kemudian diuapkan dengan rotary evaporator hingga diperoleh ekstark kental Turbinaria ornata (Turner) J. Agardh dan disimpan dalam wadah gelas tertutup sebelum digunakan untuk pengujian.

\section{Fraksinasi}

Fraksinasi dilakukan dengan metode fraksinasi cair-cair menggunakan corong pisah. Sebanyak $10 \mathrm{~g}$ ekstrak etanol Turbinaria ornata (Turner) J. Agardh dilarutkan dengan metanol sebanyak $100 \mathrm{~mL}$. Setelah sampel larut dimasukan ke dalam corong pisah dan ditambahkan pelarut nheksan sebanyak $100 \mathrm{~mL}$. Sampel kemudian dikocok berulangkali dalam corong pisah dan dibiarkan hingga membentuk dua lapisan yaitu lapisan metanol dan lapisan n-heksan. Selanjutnya masing-masing lapisan metanol dan n-heksan ditampung dalam wadah yang berbeda. Lapisan n-heksan selanjutnya dievaporasi menggunakan rotary evaporator hingga kental lalu ditimbang dan diperoleh fraksi n-heksan.

Lapisan metanol dimasukan kedalam corong pisah dan ditambahkan pelarut etil asetat sebanyak $100 \mathrm{~mL}$. Sampel dibiarkan membentuk dua lapisan yaitu lapisan metanol dan lapisan etil asetat. Selanjutnya masing masing lapisan metanol dan etil asetat ditampung dalam wadah yang berbeda. Lapisan etil asetat selanjutnya dievaporasi menggunakan rotary evaporator hingga kental lalu ditimbang dan diperoleh fraksi etil asetat, lapisan metanol yang telah ditampung divaporasi menggunakan rotary evaporator hingga kental lalu ditimbang dan diperoleh fraksi metanol. Ketiga fraksi yang diperoleh selanjutnya digunakan dalam pengujian antibakteri.

\section{Sterilisasi Alat}


Alat-alat gelas yang digunakan dalam penelitian ini disterilkan dengan menggunakan autoklaf pada suhu $121{ }^{\circ} \mathrm{C}$ selama 15 menit. Sedangkan pinset, jarum ose dan L glass dipijarkan diatas api bunsen (Ortez, 2005).

\section{Pembuatan Media NA}

Ditimbang sebanyak 10,08 g kemudian dilarutkan dengan aquadest dan dicukupkan volumenya hingga $360 \mathrm{~mL}$ dan diaduk hingga homogen. Media yang telah homogen kemudian disterilkan dengan menggunakan autoklaf pada suhu $121^{\circ} \mathrm{C}$ selama 15 menit, dan dibiarkan sampai media cukup dingin. Selanjutnya media nutrien agar dituang masing-masing sebanyak $20 \mathrm{~mL}$ ke dalam 18 cawan petri steril dan dibiarkan hingga memadat.

\section{Pembuatan Media Agar Miring}

Pembuatan agar miring nutrient agar dilakukan dengan memasukkan $10 \mathrm{~mL}$ media yang telah disterilkan dalam tabung reaksi selanjutnya disumbat dengan kapas steril dan dimiringkan sekitar $45^{\circ}$ hingga memadat dan disimpan pada suhu $2-8{ }^{0} \mathrm{C}$.

\section{Pembuatan Larutan Standar Mc. Farland 0,5}

Larutan $\mathrm{H}_{2} \mathrm{SO}_{4} 1 \%$ sebanyak $9,95 \mathrm{~mL}$ dicampurkan dengan larutan $\mathrm{BaCl}_{2} \cdot 2 \mathrm{H}_{2} \mathrm{O}$ $1,75 \%$ sebanyak $0,05 \mathrm{~mL}$ dalam erlenmeyer, kemudian dikocok sampai terbentuk larutan yang keruh. Larutan ini dipakai sebagai standar/ pembanding kekeruhan suspensi bakteri uji (Victor, 1980).

\section{Pembuatan Suspensi Bakteri Uji}

Bakteri uji yaitu Staphylococcus aureus dan Escherchia coli yang telah diinokulasi diambil \pm 1 ose dan disuspensikan kedalam tabung yang berisi $10 \mathrm{~mL}$ larutan $\mathrm{NaCl} 0,9 \%$.
Selanjutnya dibandingkan kekeruhannya dengan larutan standar Mc farland 0,5 .

\section{Kontrol Positif dan Kontrol Negatif}

Kontrol positif untuk pengujian aktivitas antibakteri ini menggunakan paper disc Kloramfenikol. Kontrol negatif menggunakan aquadest.

\section{Pembuatan Larutan Uji}

Dibuat larutan stok dengan konsentrasi $100 \%$ dengan cara menimbang $1 \mathrm{~g}$ fraksi metanol, fraksi etil asetat dan fraksi n-heksan kemudian masing-masing dilarutkan dengan aquadest hingga $1 \mathrm{~mL}$

1. Larutan uji fraksi metanol $10 \%, 20 \%$ dan $30 \%$ dibuat dengan cara mengambil masing-masing sebanyak $0,1 \mathrm{~mL}, 0,2$ $\mathrm{mL}$ dan $0,3 \mathrm{~mL}$ untuk setiap konsentrasi dan dicukupkan volumenya dengan aquades hingga $1 \mathrm{~mL}$

2. Larutan uji fraksi etil asetat $10 \%, 20 \%$ dan $30 \%$ dibuat dengan cara mengambil masing-masing sebanyak $0,1 \mathrm{~mL}, 0,2$ $\mathrm{mL}$ dan $0,3 \mathrm{~mL}$ untuk setiap konsentrasi dan dicukupkan volumenya dengan aquades hingga $1 \mathrm{~mL}$

3. Larutan uji fraksi n-heksan 10\%, $20 \%$ dan $30 \%$ dibuat dengan cara mengambil masing-masing sebanyak $0,1 \mathrm{~mL}, 0,2$ $\mathrm{mL}$ dan $0,3 \mathrm{~mL}$ untuk setiap konsentrasi dan dicukupkan volumenya dengan aquades hingga $1 \mathrm{~mL}$

\section{Pengujian Aktivitas Antibakteri}

Metode yang digunakan dalam penelitian ini yaitu metode difusi agar (disc diffusion Kirby dan Bauer). Pengujian aktivitas antibakteri menggunakan bakteri uji Staphylococcus aureus ATCC 25923 dan Escherichia coli ATCC 25922. Dalam pengujian digunakan kertas cakram berukuran $6 \mathrm{~mm}$ dengan daya serap $50 \mu \mathrm{L}$ tiap cakram. 
Disiapkan larutan uji fraksi n-heksan, fraksi etil asetat dan fraksi metanol dengan konsentrasi $10 \%, 20 \%$ dan 30\%. Selanjutnya media NA dituang masing-masing sebanyak $20 \mathrm{~mL}$ ke dalam 18 cawan petri hingga memadat. Pada permukaan media yang sudah memadat dimasukan suspensi bakteri uji, kemudian kertas cakram dicelup dengan larutan uji dan diletakan kertas cakram pada permukaan media bersama dengan kontrol positif dan dan kontrol negatif. Selanjutnya diinkubasi selama $1 \times 24$ jam pada suhu $37^{\circ} \mathrm{C}$ (Volk dan Wheeler, 1993).

\section{Pengamatan dan Pengukuran Zona Bening}

Pengamatan dilakukan setelah 1 x 24 jam masa inkubasi. Daerah bening pada sekitaran cakram menunjukan kepekaan bakteri terhadap antibiotik atau aktivitas antibakteri dari bahan uji yang digunakan dapat ditentukan berdasarkan diameter zona bening. Diameter zona bening diukur dalam satuan milimeter (mm) menggunkan jangka sorong dengan cara diukur diameter zona bening horizontal ditambahkan dengan diameter zona bening vertikal lalu dibagi dua. Kemudian hasil pengukuran zona bening, dibandingkan berdasarkan teori menurut Davis and Stout (1971).

\section{HASIL DAN PEMBAHASAN Ekstraksi dan Fraksinasi}

Sampel Turbinaria ornata (Turner) J. Agardh yang telah diambil dari perairan Teluk Manado dicuci bersih kemudian sampel dipotong kecil-kecil yang bertujuan untuk memperbesar luas permukaan sampel sehingga proses ekstraksi berjalan dengan optimal karena semakin luas permukaan sampel maka interaksi antara sampel dan pelarut akan semakin besar (Mardiyah et al, 2014). Metode ekstraksi yang digunakan ialah metode maserasi. Proses ekstraksi ini bertujuan untuk memisahkan atau menyari senyawa aktif yang ada didalam sampel, dengan adanya proses pemisahan dua komponen atau lebih yang terkandung dalam sampel oleh suatu pelarut (Suryanto, 2012).

Tujuan pemilihan metode maserasi karena cara pengerjaan dan peralatan yang digunakan sederhana serta mudah dilakukan dan metode ini juga dipilih karena tidak menggunakan pemanasan sehingga sesuai untuk golongan senyawa yang tidak tahan pemanasan. Menurut Harborne (1987), jenis dan mutu pelarut yang digunakan menentukan keberhasilan proses ekstraksi dimana pelarut yang digunakan harus dapat melarutkan zat yang diinginkan, mempunyai titik didih yang rendah, murah, tidak toksik dan tidak mudah terbakar. Untuk metode maserasi sendiri digunakan pelarut etanol $96 \%$.

Pemilihaan etanol $96 \%$ dalam proses maserasi ini adalah karena pelarut ini bersifat selektif, ekonomis, tidak beracun, bersifat universal yang cocok untuk mengekstrak semua golongan senyawa metabolit sekunder dan dapat mencegah pertumbuhan mikroorganisme (Kristanti et al., 2008). Etanol 96\% karena lebih mudah berpenetrasi ke dalam simplisia atau sampel dari pada pelarut etanol dengan konsentrasi yang lebih rendah sehinga ekstrak yang akan dihasilkan akan pekat (Jusnita et al, 2017)

Maserat yang diperoleh dari proses maserasi selanjutnya dipekatkan dengan menggunakan alat rotary evaporator. Prinsip kerja dari alat ini ialah menggunakan prinsip vakum destilasi, dimana adanya tekanan mengakibatkan pelarut menguap pada suhu dibawah titik didihnya, sehingga kandungan senyawa metabolit sekunder yang terkandung di dalam pelarut tidak mengalami kerusakan oleh suhu yang tinggi (Hermansah et al, 2015)

Ekstrak kental yang diperoleh selanjutnya difraksinasi dengan metode fraksinasi cair-cair. Metode fraksinasi ini 
menggunakan variasi pelarut yang memiliki kepolaran yang berbeda- beda, yaitu metanol, etil asetat dan n-heksan, pemilihan ini di karena ketiga pelarut ini suadah mewakili kepolaran yang berbeda-beda dimana metanol bersifat polar, etil aseat bersifat semi polar dan n-heksan bersifat non polar sehinnga senyawa-senyawa yang memiliki kepolaran berbedah dapat terpisah kedalam pelarut yang sesuai (Voight, 1994).

Tujuan dilakukan proses fraksinasi yaitu untuk memisahkan golongan senyawa yang satu dengan golongan senyawa lainya berdasarkan tingkat kepolaran. Fraksinasi dilakukan secara berkesinambungan dimulai dengan pelarut non polar dilanjutkan dengan semi polar dan diakhiri dengan pelarut polar. Masing-masing pelarut secara selektif akan memisahkan kelompok kandungan kimia tersebut. Jumlah senyawa yang dapat dipisahkan menjadi fraksi berbeda-beda tergantung pada kandungan senyawa di tiap jenis sampel. Akhir dari proses fraksinasi akan didapatkan berturut-turut senyawa non polar, semi polar dan polar (Purwanto, 2015).

\section{Pengujian Aktivitas Antibakteri Turbinaria ornata (Turner) J. Agardh}

Pengujian aktivitas antibakteri fraksi metanol, fraksi etil asetat dan fraksi n-heksan pada bakteri uji Staphylococcus aureus dan Escherichia coli.Pengujian aktivitas antibakteri menggunakan metode difusi agar (disc diffusion Kriby and Bauer). Metode ini dilakukan dengan menggunakan kertas cakram yang berisi senyawa antibakteri, kemudian diletakkan pada media padat yang telah diinokulasi bakteri.

Senyawa antibakteri akan berdifusi ke dalam media padat yang diinokulasi bakteri dan menghambat pertumbuhan bakteri yang ditandai dengan terbentuknya daerah bening di sekeliling kertas cakram (Brooks et al., 2005). Metode ini dipilih karena pengerjaan yang sederhana, mudah dikerjakan, ketelitian, tidak

memerlukan peralatan yang khusus, metode serbaguna bagi semua bakteri patogen yang tumbuh cepat dan sering digunakan dalam uji kepekaan antibiotik dalam program pengendalian mutu.

Hasil pengujian menunjukan bahwa terbentuk zona bening disekitar kertas cakram yang menunjukan bahwa adanya aktivitas antibakteri dari larutan uji dan kontrol positif yang digunakan. Pengamatan dilakukan setelah di inkubasi pada suhu $37^{\circ} \mathrm{C}$ selama $1 \mathrm{x}$ 24 jam serta dilakukan pengulangan sebanyak 3 kali. Pengulangan ini dilakukan untuk lebih mengakuratkan hasil yang akan diperoleh.

Hasil pengujian yang didapat dari pengukuran rata-rata diameter zona bening dari antibakteri fraksi metanol, fraksi etil asetat, fraksi n-heksan, kontrol positif dan kontrol negatif terhadap bakteri uji Staphylococcus aureus dan Eschericia coli.

Tabel 1. Hasil rata-rata pengujian fraksi metanol, fraksi etil asetat, fraksi n-heksan, kontrol positif dan kontrol negatif terhadap bakteri uji Staphylococcus aureus

\begin{tabular}{l|llllll}
\hline \multicolumn{7}{c}{ Rata-rata diameter $(\mathrm{mm})$ pada tiga konsentrasi } \\
\hline & $10 \%$ & Kategori & $20 \%$ & Kategori & $30 \%$ & Kategori \\
\hline Fraksi matanol & 11,25 & Kuat & 12,25 & Kuat & 12,58 & Kuat \\
\hline Fraksi etilasetat & 9,00 & Sedang & 9,75 & Sedang & 10,50 & Kuat \\
\hline
\end{tabular}


PHARMACON- PROGRAM STUDI FARMASI, FMIPA, UNIVERSITAS SAM RATULANGI,

Volume 8 Nomor 2 Mei 2019

\begin{tabular}{lllllll}
\hline Fraksi n-heksan & 12,25 & Kuat & 13,80 & Kuat & 14,16 & Kuat \\
\hline Kontrol + & 15,00 & Kuat & 15,50 & Kuat & 15,00 & Kuat \\
\hline Kontrol - & 0 & & 0 & & 0 &
\end{tabular}

Tabel 2. Hasil rata-rata pengujian fraksi metanol, fraksi etil asetat, fraksi n-heksan, kontrol positif dan kontrol negatif terhadap bakteri uji Eschericia coli

\begin{tabular}{|c|c|c|c|c|c|c|}
\hline \multicolumn{7}{|c|}{ Rata-rata diameter (mm) pada tiga konsentrasi } \\
\hline & $10 \%$ & Kategori & $20 \%$ & Kategori & $30 \%$ & Kategori \\
\hline Fraksi matanol & 10,30 & Kuat & 11,41 & Kuat & 12,60 & Kuat \\
\hline Fraksi etilasetat & 10,80 & Kuat & 12,83 & Kuat & 13,16 & Kuat \\
\hline Fraksi n-heksan & 9,75 & Sedang & 10,41 & Kuat & 11,58 & Kuat \\
\hline Kontrol + & 16,00 & Kuat & 17,00 & Kuat & 17,00 & Kuat \\
\hline Kontrol - & 0 & & 0 & & 0 & \\
\hline
\end{tabular}

menggunakan kontrol positif dan kontrol negatif. Kontrol positif digunakan antibiotik kloramfenikol karena bersifat menghambat pertumbuhan bakteri (bakteriostatik) dan berspektrum luas dimana bisa digunakan pada bakteri Gram posif maupun bakteri Gram negatif (Katzung, 2004). Kontrol positif berfungsi sebagai pembanding antara antibakteri yang sudah terstandarisasi dengan larutan fraksi dalam hal ini Turbinaria ornata (Turner) J. Agardh. Kontrol negatif yang digunakan yaitu aquades. Fungsi dari kontrol negatif ini untuk mengetahui ada tidaknya pengaruh pelarut terhadap pertumbuhan bakteri, sehingga dapat diketahui bahwa aktivitas antibakteri yang dihasilkan bukan berasal dari pelarut yang digunakan melainkan berasal dari aktivitas senyawa yang terdapat dalam sampel Turbinaria ornata Turner) J. Agardh.

Pada penelitian ini ketiga seri konsentrasi baik fraksi metanol, fraksi etil asetat dan fraksi n-heksan menunjukan adanya aktivitas antibakteri dalam menghambat bakteri Staphylococcus aureus dan Escherichia coli ditunjukan dengan anol dan fraksi n-heksan memiliki perbedaan diameter zona bening pada bakteri Staphylococcus aureus Gram positif dibandingkan Escherichia coli Gram negatif. Hasil yang

berbeda dari kedua golongan bakteri terhadap senyawa antibakteri ini dikarenakan adanya perbedaan kepekaan pada bakteri Gram positif dan bakteri Gram negatif terhadap senyawa antibakteri yang terkandung dalam fraksi Turbinaria ornata (Turner) J. Agardh. Hal ini dikarenakan adanya perbedaan struktur dinding sel yang dimiliki oleh masing-masing bakteri.

Bakteri S. aureus merupakan bakteri Gram positif dimana jenis bakteri ini 
memiliki struktur dinding sel yang terdiri dari lapisan peptidoglikan yang tebal, dinding sel mengandung polisakrida (asam teikoat) dan sedikit lipid (Ibrahim, 2007). Kerusakan sel bakteri tersebut akan menyebabkan terhambatnya biosintesis enzim-enzim spesifik yang diperlukan dalam suatu reaksi metabolisme. Sedangkan E. coli merupakan bakteri Gram negatif memiliki struktur dinding sel lebih banyak mengandung lipid, sedikit peptidoglikan dan memiliki membran luar berupa bilayer yang berfungsi sebagai pertahanan selektif untuk senyawa-senyawa yang keluar dan masuk dalam sel bakteri (Pelczar, 1998).

Hasil yang diperoleh menunjukkan diameter zona bening bakteri Staphylococcus aureus dan Escherichia coli yang terbentuk pada konsentrasi fraksi 30\% lebih besar dibandingkan dengan konsentrasi fraksi $10 \%$ dan 20\%. Hal ini membuktikan bahwa semakin tinggi konsentrasi larutan uji, maka semakin besar diameter zona bening yang terbentuk. Menurut Ajizah (2004), selain faktor konsentrasi, jenis bahan antibakteri juga menentukan kemampuan menghambat pertumbuhan bakteri.

Penelitian yang dilakukan oleh Neelamathi dan Kannan, (2015) mengenai skrining fitokimia dan karakteristik senyawa bioaktif dari ekstrak Turbinaria ornata (Turner) J. Agardh menunjukan adanya senyawa alkaloid, fenolik, tanin, steroid, flavonoid dan terpenoid yang memiliki manfaat sebagai antibakteri. Beberapa penelitian yang telah dilakukan juga menunjukan bahwa senyawa steroid diduga memiliki aktivitas antibakteri terhadap bakteri Staphylococcus aureus dan Escherichia coli. Penelitian lain yang dilakukan Vijayabaskar dan Shiyamala, (2011) menunjukan bahwa ekstrak dari Turbinaria ornata (Turner) J. Agardh memiliki aktivitas antibakteri terhadap bakteri Staphylococcus aureus dan Escherichia coli.

Hasil yang diperoleh dari uji skrining fitokima menunjukan bahwa ekstrak Turbinaria ornata (Turner) J. Agardh terkandung senyawa alkaloid, flavonoid, steroid, tanin dan fenolik. Sehingga dapat diketahui aktivitas antibakteri yang dihasilkan dari fraksi Turbinaria ornata (Turner) J. Agardh berasal dari senyawa alkaloid, flavonoid, steroid, tanin dan fenolik.

\section{KESIMPULAN}

Berdasarkan hasil penelitian yang telah dilakukan dapat disimpulkan bahwa fraksi alga Turbinaria ornata (Turner) J. Agardh yang diperoleh dari Perairan Teluk Manado memiliki daya antibakteri terhadap bakteri Staphylococcus aureus dan Eschericia coli. Fraksi metanol konsentrasi 10\%. 20\% ,30\%, fraksi etil asetat konsentrasi 30\%, dan fraksi n-heksana konsentrasi 20\%, 30\% memiliki aktivitas antibakteri yang dikategorikan kuat pada kedua bakteri yaitu $S$. aureus dan $E$. coli.

\section{Saran}

Perlu dilakukan penelitian lebih lanjut untuk identifikasi senyawa aktif pada fraksi nheksan yang menampakan fraksi dengan aktivitas antibakteri terbesar.

\section{DAFTAR PUSTAKA}

Books, G.F., Butel, J.S., More, S.A. 2008. Mikrobiologi Kedokteran Jawetz, Melnick and Adelbreg. Edisi 23. Terjemahan Hartanto, H., Rachman, C., Damanti, D., Dani, Aryana, D. EGC, Jakarta.

Cowan, M. M. 1999. Plant Products as Antimicrobial Agents. Clinical Microbiology Reviews. 12: 564 - 582 
Dali, S., Natsir, H., Usman, H., Ahmad, A.. 2011. Bioaktivitas Antibakteri Fraksi Protein Alga Merah Gelidium Amansii Dari Perairan Cikoang Kabupaten Takalar Sulawesi Selatan. Fakakultas MIPA Universitas Hasanuddin, Makassar

Davis, W.W and Stout, T.R. 1971. Disc Plate Methods of Microbiological Antibiotic Assay. Microbiology. 22(4): 659-665.

Harborne, J. B. 1987. Metode Fitokimia. Edisi ke-2. ITB. Bandung.

Ibrahim M, 2007. Mikrobiologi: Prinsip dan Aplikasi. Unesa University Press, Surabaya.

Islami, F., Ridho, A., Pramesti, R. 2014. Aktivitas Antioksidan Ekstrak Rumput Laut Turbinaria Decurrens Bory De Saint-Vincent Dari Pantai Krakal, Gunung Kidul, Yogyakarta. Journal of Marine Research. 3(4): 605-616.

Jawetz, E., Melinick, J. L., Adelbreg, F.A. 1986. Mikrobiologi Kedokteran, Penerbit BK. Kedokteran. EGC, Jakarta， : 609-610，627-629，638639.

Juariah, S. 2014. Aktivitas Senyawa Antibakteri Bintang Laut (Asterias forbesii) Terhadap Beberapa Jenis Bakteri Patogen. [Tesis]. Fakultas Matematika dan Ilmu Pengetahuan Alam, Universitas Sumatera Utara, Medan.

Katzung, Betram G. 2004. Farmakologi Dasar dan Klinik edisi 4. Alih Bahasa : Staf Dosen Farmakologi Fakultas Kedokteran Universitas Sriwijaya. EGC, Jakarta. 709-719.
Kristanti, A.N., Aminah, N.S.,Tanjung, B.K. 2008. Buku Ajar Fitokimia. Universitas Airlangga Press, Surabaya.

Mardiyah, U., Fasya, G. A. Fauziyah, B., dan Amalia, S. 2014. Ekstraksi Uji Aktivitas Antioksidan dan Identifikasi Golongan Senyawa Aktif Alga Merah Eucheuma spinosum dari Perairan Banyuwangi. Jurnal Achemy. 3(1):42

Maulida D. dan Naufal Z. 2010. Ekstraksi Antioksidan (Likopen) Dari Buah Tomat Dengan Menggunakan Solvent Campuran, N-heksana, Aseton dan Etanol. [Skripsi]. Universitas Dipenegoro.

Neelamathi, E. I and Kannan, R. 2015. Screening and Characterization of Bioactive Compounds of Turbinaria Ornata from the Gulf of Mannar. International Advanced Research Journal in Science, Engineering and Technology 2(11)

Pankey, G. A., dan Sabbath, L. D., 2004, Clinical Relevance of Bacteriostatic Versus Bactericidal Mechanism of Action in the Treatment of Gram Positive Bacterial Infections, Clin. Infec. 38: 864- 870.

Paul, J. P. 2014. Histochemistry And Fluorescence Analysis Turbinaria Ornata (Turner) J.Ag. - A Brown ImportantSeaweed (Phaeophyceae). Journal of Indian Plant Sciences 3(1)

Pelczar, J.M. 1998. Dasar-Dasar Mikrobiologi Jilid 2. Alih Bahasa: Ratna Ratna Siri Hadiotomo. UI Press, Jakarta.

Pramono, S. 2013. Teknologi Fitofarmasetik (Proses Produksi Ekstark untuk 
Sediaan Obat Alam), Bahan Ajar

Galenika. Fakultas Farmasi

Universitas Gadjah Mada,

Yogyakarta.

Purwanto, S. 2015. Uji aktivitas Antibakteri

Fraksi Aktis Ekstark Daun Seggani

(Melastoma malabathricum)

Terhadap Escherichia coli. Jurnal

Keperawatan Sriwijaya. 2(2).

Rahaweman, A.C. 2016. Aktivitas Antibakteri dan Isolasi Fraksi Aktif Kapang Endofit Makroalga Chlorophyta dan Phaeophyta [Tesis]. Program Studi Teknologi Hasil Perairan, Sekolah Pascasarjana, Institut Pertanian Bogor, Bogor.

Robinson, T. 1995. Kandungan Organik Tumbuhan Tinggi. Penerjemah: Padmawinata, K. Penerbit ITB, Bandung.

Varier, K.M., Milton, M.C., Arulvasu, C., Gajendran, B. 2013. Evaluation of Antibacterial Properties of Selected Red Seaweeds from Rameshwaram Tamil Nadu India. Journal of Acamedia and Industrial Research. 1 (1): 667-670.

Victor, L. 1980. Antibiotics Tradisional Sebagai Pengobatan Alternatif harus Dilestarikan. Karya Ilmiah. FKM USU, Medan.

Vijayabaskar, P. and Shiyamala, V. 2011. Antibacterial Activities of Brown Marine Algae (Sargassum wightii and Turbinaria ornata) from the Gulf of Mannar Biosphere Reserve. Advances in Biological Research 5 (2): 99-102.

Volk, W.A. Wheeler, M.F. 1993. Mikrobiologi Dasar. Terjemahan
Markham. PT. Glora Aksara Pratama, Jakarta. 